\title{
THE CRIME OF FALSE PRETENSES IN THE CONTEXT OF COMMERCIAL CREDIT TRANSACTIONS*
}

EVERY state has a statute providing for criminal punishment of any person who. with intent to defraud, obtains something of value from another by false pretenses. ${ }^{1}$ Under such statutes the states prosecute not only swindlers and confidence men, ${ }^{2}$ but also buyers of goods on credit and borrowers who make false statements concerning their financial status, ${ }^{3}$ their share in the ownership of property being used to secure debts, ${ }^{4}$ or the existence and value of liens on such property. ${ }^{5}$ But when false pretenses statutes are extended beyond obvious criminality to the misdeeds of businessmen, difficult problems arise. In policy terms, the problem is how to accomplish the goal of deterring and punishing misrepresentations, without at the same time establishing an unreasonably strict standard for commercial conduct and permitting misuse of the criminal law by

*Nelson v. United States, 227 F.2d 21 (D.C. Cir. 1955).

1. There are, however, several types of false pretenses statutes. Cal. Pen. Code Ann. $\$ 484$ (1951) (incorporated in larceny statute); Mass. ANw. Laws c. 266, $\$ \$ 30,33-35$ (1933) (same); Mircr. Stat. ANn. \& 28.415 (1938) (independent offense); Pa. Stat. ANN. tit. 18, $\$ 4836$ (Purdon 1945) (same) ; GA. CoDE ANN. $\$ \$ 26-7401$ - 26-7410 (1953) (fraudulently obtaining credit) ; OKLA. STAT. ANN. tit. 21, \$1541 (1937) (directed at confidence game; punishes attempts); TEx. Pen. Code ANN. arts. 1413, 1545 (Vernon 1953) (theft by false pretext; swindling).

False pretenses differs from larceny in that the victim of an obtaining by false pretenses intends to pass title in the property to the swindler. E.g., Forrest v. State, 117 Tex. Crim. 556, 34 S.W.2d 1102 (1931).

2. People v. Gordon, 71 Cal. App. 2d 606, 163 P.2d 110 (1945) (oil land swindle); People v. Walker, 69 Cal. App. 475, 231 Pac. 572 (1924) (faith healer); People v. Miller, 278 I1l. 490, 116 N.E. 131 (1917) (confidence game); Commonwealth v. Coshnear, 289 Mass. 516, 194 N.E. 900 (1935) (stock swindle) ; Attwell, Confidence Game in Illinois, 49 Nw. U.L. REv. 737 (1955).

For a description of the "long firm swindle," which is a major target of false pretense's statutes in the commercial context, see Dilnot, Gerting Rich Quick: Aiv OUTLINe of Swindles Old and New with Some Account of the Manners and Custons of ConFIDENCE MEN 232-36 (1935). In this variant of commercial fraud, the swindler obtains larger and larger shipments of goods on credit. All bills are paid promptly except the last, the largest of all. See also MacDonald, "Crime is a Business": Buncos-RAcketsConfidence Scheares 1\$3-222 (1939).

3. E.g., Carr v. State, 60 Ga. App. 590, 4 S.E.2d 500 (1939) ; State v. Lamoreaux, 13 N.J. Super. 99, 80 A.2d 213 (App. Div. 1951).

Most states also have special statutes which punish as a misdemeanor the making of false financial statements in writing with intent that they be relied upon, but not necessarily with intent to defraud. E.g., Mo. Ann. Stat. $\$ 561.400$ (Vernon 1953); N.J. Stat. Ann. $\$ 2 A$ :111-\$ (1953). See also Schayer v. People, 5 Colo. App. 75, 37 Pac. 43 (1894), interpreting what is now CoLo. Rev. STat. $\$ 40-14-13$ (1953).

4. E.g., Wilson v. State, $\$ 4$ Ga. App. 703, 67 S.E.2d 164 (1951) ; Odom v. State, 130 Miss. 643, 94 So. 233 (1922), aff'd after retrial, 132 Miss. 3, 95 So. 253 (1923) ; State v. Whecler, 101 Wash. 293, 172 Pac. 225 (1918).

5. E.y., People v. Lee, 259 Mich. 355, 243 N.W. 227 (1932) : State v. Richardson, 228 S.W. 789 (Mo. 1921) ; Speckels v. State, 130 Tex. Crim. 639, 95 S.W.2d 122 (1936). 
militant creditors. These conflicting considerations have led courts to differ on the legal question whether the crime is complete when the creditor is induced to extend credit without having all the facts before him, ${ }^{6}$ or whether ultimate pecuniary loss must be shown. ${ }^{7}$ And in jurisdictions where loss is not an element of the crime, courts differ on the question whether proof of loss is admissible to prove the debtor's intent to defraud. ${ }^{8}$

In Nelson v. United States ${ }^{9}$ the Court of Appeals for the District of Columbia Circuit held that loss was not a necessary element of the crime of false pretenses under the local statute, ${ }^{10}$ but that evidence of loss was nevertheless admissible to prove intent to defraud. The defendant Nelson, a television retailer, had purchased several sets worth a total of $\$ 272$ from a wholesaler on credit.11 The purchase price was secured by a chattel mortgage on the goods and on a car in which Nelson claimed to have a $\$ 4,260$ interest. ${ }^{12}$ In reality Nelson's car was encumbered by a prior lien, so that his interest was worth only about $\$ 1,000$. Thereafter, this equity was lost when the car was damaged in an accident to the extent of $\$ 1,000$. Nelson defaulted on his obligation for the price of the television sets and was tried for defrauding the wholesaler by means of false pretenses. At trial he was convicted and sentenced to imprisonment for a term of one to three years, ${ }^{13}$ and, with one judge dissenting, the court of appeals affirmed.

6. Kay v. United States, 303 U.S. 1, 5-6 (1938) ; United States v. Rowe, 56 F.2d 747, 749 (2d Cir. 1932) ; In re Rudebeck, 95 Wash. 433, 163 Pac. 930 (1917) ; 2 Wharton, Criminal Law \& 1409 (12th ed. 1932).

7. Wilson v. State, 84 Ga. App. 703, 710, 67 S.E.2d 164, 170 (1951) ; State v. Palmer, 50 Kan. 318, 324, 32 Pac. 29, 30 (1893) ; State v. Morris, 85 Utah 210, 216, 38 P.2d 1097, 1100 (1934); 2 Bishop, Crininal Law $\$ 417$ (4) (9th ed. 1923); 2 Burdrck, Law of CRINE $\$ 648$ (1946).

8. Compare Meek v. State, 117 Ala. 116, 23 So. 155 (1898) (loss inadmissible); State v. Cadwell, 105 Wash. 689, 179 Pac. 87 (1919) (offer of restitution inadmissible), with Simmons v. State, 160 Miss. 582, 135 So. 196 (1931) (absence of loss admissible).

9. 227 F.2d 21 (D.C. Cir. 1955).

10. "Whoever, by any false pretense, with intent to defraud, obtains from any person anything of value, or procures the execution and delivery of any instrument of writing or conveyance of real or personal property ... shall, if the value of the property ... so obtained . . . is $\$ 50$ or upward, be imprisoned not less than one year nor more than three years. ..." D.C. CODE ANN. \$ 22-1301 (1951).

11. Nelson v. United States, 227 F.2d 21, 23 (D.C. Cir. 1955). Defendant had dealt with the wholesaler over a period of months and was indebted to him in the amount of about $\$ 1800$ at the time of this final purchase. The parties had previously done $\$ 25,000$ worth of business on credit, and all payments were made on time by the debtor. Id. at 26.

12. Id. at 23 . The mortgages secured a note of $\$ 2,047.37$, which represented a pre-existing indebtedness in excess of $\$ 1800$ as well as the new purchase. In accordance with the weight of authority, e.g., State v. Tower, 122 Kan. 165, 251 Pac. 401 (1926) ; Dill v. State, 109 Neb. 402, 191 N.W. 642 (1922) ; Midgley v. State, 29 Okla. Crim. 108, 232 Pac. 967 (1925), the court did not consider the extension of the pre-existing indebtedness as a possible subject of an obtaining by false pretenses. Consequently, it held that the relevant defrauding concerned only the $\$ 272$ purchase. Nelson v. United States, 227 F.2d 21,27 (D.C. Cir. 1955).

13. Transcript of Record, p. 150, Nelson v. United States, 227 F.2d 21 (D.C. Cir. 1955). 
The court reasoned that Nelson defrauded his creditor by depriving him of the right to bargain with all the facts before him $;^{14}$ consequently, it was immaterial that the security Nelson actually provided was five times as great as the debt he was covering. ${ }^{15}$ However, while actual loss was not a necessary element of the crime, it was not irrelevant. For the court considered it necessary for the prosecution to prove that the defendant intended to deprive his victim permanently of the value of the goods. So long as the defendant's lie was told knowingly, the court held, the requisite intent might be presumed from the fact that the lie ultimately resulted in loss or injury. ${ }^{16}$

The court's reasoning is unsatisfactory because it rests upon inapposite authority and is internally inconsistent. To conclude that the crime of false pretenses is complete when a victim is deprived of his right to bargain with all the facts, the court relied on cases construing mail fraud and HOLC credit application statutes. ${ }^{17}$ But these provisions establish a stricter standard than false pretenses statutes; they are designed to protect the United States from being an agent or victim of even an attempted fraud. ${ }^{18}$ The other decision cited by

14. Nelson v. United States, 227 F.2d 21, 25 (D.C. Cir. 1955). See notes 17-18 infra and accompanying text.

15. Nelson v. United States, supra note 14 , at 25 . The dissenting judge calculated that the security was worth three times the amount of the debt because it secured the price of a washing machine as well as the television sets. Id. at 27.

16. Id. at 25, citing Agnew v. United States, 165 U.S. 36, 53 (1897).

17. Nelson v. United States, 227 F.2d 21, 25 (D.C. Cir. 1955). United States v. Rowe, 56 F.2d 747 (2d Cir. 1932), arose under the federal mail fraud statute, 18 U.S.C. $\S 1341$ (1952), and Kay v. United States, 303 U.S. 1 (1938), concerned misrepresentations made punishable by the Home Owners' Loan Corporation Act, 18 U.S.C. $\$ 1014$ (1952). See nate is infra.

18. The federal mail fraud statute provides:

"Whocver, having devised or intending to devise any scheme or artifice to defraud, ... . for the purpose of executing such scheme or artifice or attempting so to do, ... [uses the mails] shall be fined ... or imprisoned ... or both."

18 U.S.C. $\$ 1341$ (1952). Compare the HOLC Act:

"Whoever knowingly makes any false statement or report, or willfully overvalues any land, property or security, for the purpose of influencing in any zuay the action of ... the Home Owners' Loan Corporation ... upon any application . . . shall be fined . . or imprisoned . . or both."

1 S U.S.C. $\$ 1014$ (1952). (Emphasis added.)

Compare the policy of these statutes with that of laws making punishable the drawing of a check on a bank if the drawer has no account or lacks sufficient funds in the bank for the check to be honored. E.g., CAL. Pen. Code $\$ 476 \mathrm{a}$ (1949); I Ind. Stat. ANw. $\$ 10-2105$ (Eurns 1933) (maling, drawing, uttering or delivering check known to be bad is "prima facie evidence of intent to defraud"); MrNN. Srat. AnN. $\$ 622.04$ (1947) (similar). The prolicy of bad check statutes is primarily to protect the reliability of a particular type of negotiable instrument and secondarily to protect individual payees from loss. Consequently, a drawer may be convicted although there was money in the bank and he was prepared to make good the worthless check. People v. Freedman, 111 Cal. App. 2d 611, 245 P.2d 45 (1952); People v. Khan, 41 Cal. App. 393, 182 Pac. 803 (1919); see Clagett v. United States, 289 Fed. 532 (D.C. Cir. 1923) ; cf. State v. Nelson, 58 S.D. 562, 237 N.W. 766 (1931). 
the court concerned a buyer defrauded in a cash transaction. ${ }^{19}$ However, any loss which a cash buyer suffers is complete at the time of the transaction, whereas it cannot be known with certainty whether a creditor will suffer a loss until his claim ripens and remains unpaid. ${ }^{20}$ More important, the court was inconsistent in holding that the victim was defrauded when he was deceived but that Nelson's intent to defraud was dependent on an accidental loss which occurred subsequently. The fallacy of such reliance upon subsequent events to prove intent has been pointed out by other courts. ${ }^{21}$ And the Nelson court need not have adopted a retrospective argument. It could have been consistent and found intent to defraud from the defendant's knowing falsehood, avoiding any reference to subsequent loss. ${ }^{22}$ But perhaps sensing the harshness of punishing misrepresentation without regard to whether harm actually results, the court agreed with the trial judge that intent to defraud may be inferred only when the lie results in actual loss to the creditor. ${ }^{23}$ Yet it is seldom possible to prove intent to cause ultimate injury without the aid of a presumption, for direct proof of subjective intent is palpably difficult to produce. ${ }^{24}$ Therefore, despite the court's holding that loss is not an element of the crime, the practical result of its ruling on the intent issue is that prosecutions for false pretenses can succeed only when loss is shown.

The court's attempts to make actual loss to the creditor a prerequisite to conviction for false pretenses appear to stem from a persistent belief that untruth, per se, is insufficient ground for imposition of criminal punishment. ${ }^{2 \overline{5}}$ The law

19. The court quoted from Robinson v. United States, 42 App. D.C. 186, 192 (1914). See Nelson v. United States, 227 F.2d 21, 24 (D.C. Cir. 1955).

20. Compare Chase \& Schlink, Your Money's Worth: A Study in the Waste of the Consumer's Dollar 76-120 (1927) (fraud on buyers), with Irons, Commercial Credit and Collectron Practice 481-93 (1942) (fraud on sellers).

21. Meek v. State, 117 Ala. 116, 23 So. 155 (1898) (reversible error to admit state's evidence that defendant never paid for goods obtained) ; State v. Richardson, 228 S.W. 7S9 (Mo. 1921) ; State v. Casperson, 71 Utah 68, 262 Pac. 294 (1927); see State v. Wheeler, 101 Wash. 293, 172 Pac. 225 (1918).

Evidence of subsequent events is sometimes admissible where it tends to exonerate rather than incriminate. Wilson v. State, 84 Ga. App. 703, 67 S.E.2d 164 (1951) ; Daniel v. State, 63 Ga. App. 12, 10 S.E.2d 80 (1940) ; State v. Clark, 46 Kan. 65, 26 Pac. 481 (1S91).

22. LaMoyne v. State, 53 Tex. Crim. 221, 111 S.W. 950 (1908); State v. Cook, 113 Wash. 391, 194 Pac. 401 (1920); In re Rudebeck, 95 Wash. 433, 163 Pac. 930 (1917); Anderson v. State, 27 Wyo. 345, 196 Pac. 1047 (1921).

23. Nelson v. United States, 227 F.2d 21, 25 (D.C. Cir. 1955). Until the trial judge learned there had been a loss he was prepared to dismiss the case. Id. at 26 (dissenting opinion). Accord, Bolton v. State, 43 Ga. App. 759, 159 S.E. 910 (1931).

The harshness of the rule that loss is not an element appears in LaMoyne v. State, $\mathbf{5 3}$ Tex. Crim. 221, 111 S.W. 950 (1908).

24. See note 40 infra. Intent may be proved directly by confessions, admissions, declarations against interest and declarations as to mental state. MCCorsick, EvidencE $\$ \S 109$ $19,239,253,269$ (1954).

25. E.g., People v. Holtzman, 272 I11. 447,112 N.E. 370 (1916) ; Simmons v. State, 160 Miss. 582, 135 So. 196 (1931); State v. Zingher, 302 Mo. 650, 259 S.W. 451 (1924).

Most courts, without elaborating a rationale, simply state that the broad terms of the statute must be construed narrowly. E.g., People v. Wakely, 62 Mich. 297, 28 N.W. 871 
should not punish so-called "naked" lies, the courts have urged, ${ }^{26}$ for untruths are too common and too easily condoned in the commercial world to warrant exercise of the criminal power of government unless some showing of concrete harm to the community can be made. ${ }^{27}$ This assessment of current morality seems sound, and the attempt to conform law to morality is in accord with basic policies and objectives of the criminal law. ${ }^{28}$ However, the loss rule limits the scope of false pretenses statutes both too much and not enough. Thus, if loss is an element of the crime, restitution by the defendant before prosecution may make conviction impossible even though a palpable fraud has been committed. ${ }^{29}$ In this respect the Nelson variant of the loss rule is an improvement, since intent to defraud could in such cases be inferred from the circumstances, without the aid of a presumption arising from proof or loss. But on the other hand, as the Nelson case illustrates, both forms of the loss rule permit conviction even where the misrepresentation was harmless at the outset, because adequate security was provided, and where loss resulted only by reason of accidental destruction of the security. ${ }^{30}$

A further shortcoming of loss as a touchstone of criminality is that it encourages use of the false pretenses statute as a criminal substitute for civil imprisonment for debt. In nearly every American jurisdiction, civil imprisonment for contract debts has been abolished by statute or constitutional provision. ${ }^{31}$

(1886) ; State v. Lamoreaux, 13 N.J. Super. 99, 80 A.2d 213 (App. Div. 1951) ; Commonwealth v. Hutchinson, 2 Pars. Eq. Cas. $* 309, * 311$ (Pa. C.P. 1843).

26. See State v. Penley, 27 Conn. $* 587, * 591$ (1858) (misrepresentation criminal because not a "naked lie") : State v. Palmer, 50 Kan. 318, 324, 32 Pac. 29, 30 (1893) ("It will not do to convict on general principles, because the evidence shows the defendant devoid of common honesty."); Commonwealth v. Hutchinson, supra note 25 , at $* 311$ ("Although in ethics, every misrepresentation is morally wrong; yet if so severe a standard of conduct is to be introduced into our criminal code, it is plainly to be seen that breach of contract and crime will scarcely be divided by an appreciable line. . ..") ; 2 Bishop, CRIMINaL LAw $\$ 432$ (1) (9th ed. 1923) ; cf. State v. Lamoreaux, supra note 25 , at 103,80 A.2d at 214 (lie sufficient to support tort action in fraud and deceit but not criminal indictment for false pretenses) ; 2 WhaRToN, CRIMInaL LAw $\$ \$ 1419-20$ (12th ed. 1932) (trade puffing-mere exaggerated praise or loose exaggeration of value-not indictable, for such a holding "would bring almost every sale within the statute").

27. See note 26 supra.

Harding, The Popular Practice of Fraud 22 (1935) argues that fraud is practiced as part of the normal commercial context: so-called honest businessmen are engaged in the everyday perpetration of fraud to the extent that they misrepresent their wares through untrue advertising, trade puffing and meaningless guaranties. Id. at 70-91, 183-206. Fraud is tolerated in the commercial context until it becomes an actual menace to life and health as well as to the pocketbook. Id. at $92-108,369$.

28. For discussion, see Daniel v. State, 63 Ga. App. 12, 10 S.E.2d 80 (1940) ; State v. Clark, 46 IKan. 65, 26 Pac. 481 (1891) ; State v. Casperson, 71 Utah 68, 262 Pac. 294 (1927). See also 1. Wharton, Crminal Law $\S 16$ (12th ed. 1932).

29. Cf. cases cited note 7 supra.

30. Cf. cases cited note 22 supra.

31. For review of the status of imprisonment for debt in the various American jurisdictions, see Furd, Imprisonment for Debt, $25 \mathrm{MrcH}$. L. REv. 24, 33 (1926). See also Parnass, Imprisanment for Cizril Obligations in Illinois, 15 ILL. L. Rev. 559 (1921) ; Wagner, 
Yet where a creditor can discover any misrepresentation by his debtor, as he often can, prosecution for false pretenses offers an effective substitute. ${ }^{32}$ Where misrepresentation plus loss to the creditor constitutes the crime, so that payment is an absolute defense, prosecution puts the defendant and his relatives under heavy pressure to find some way of paying the underlying debt. ${ }^{33}$ Since the loss rule makes criminality depend on payment rather than the venality or

Pennsyltania's Policy on Defiant Debtors, 59 Drck. L. Rev. 203 (1955) ; Note, To Gaol for Debt in Wisconsin, 1952 WIs. L. Rev. 764.

In many states debtors may be jailed on civil process for failure to pay debts arising from torts, and for contract debts under certain restricted circumstances. Morris v. Schwartz, 326 Ill. App. 274, 61 N.E.2d 690 (1945); Luhrig Coal Co. v. Ludlum, 69 Ohio 311, 69 N.E. 562 (1903); Hamilton, In re the Small Debtor, 42 YALE L.J. 472 (1933); Wagner, supra. In numerous respects, however, criminal conviction is more severe. Civil imprisonment may last six months. Parnass, supra at 571. But a jailyard bond is often available, and the jailyard may include the whole local community. See Dempsey v. Hollis, $116 \mathrm{Vt} .316,75$ A.2d 662 (1950). Moreover, the creditor is often responsible for his debtor's board and medical bills while he remains civily imprisoned. Note, 1952 WIs. L. REv. 764. On the other hand, criminal imprisonment may last as long for false pretenses as for larceny. McClure v. State, 174 Tenn. 140, 124 S.W.2d 240 (1939) (three years); Colo. Rev. STAT. $\$ 40-14-2$ (1.953) (ten years) ; FLA. STAT. ANN. $\$ 817.01$ (1944) (ten years and/or $\$ 500$ ) ; PA. Stat. AnN. tit. 18, $\$ 4836$ (Purdon 1945) (five years and/or \$5,000). Criminal imprisonment is, of course, paid for by the taxpayer. Moreover, one imprisoned for a crime suffers loss of civil rights, social disgrace and the economic burden of being an exconvict. See Comment, The Legal Status of Convicts During and After Incarceration, 37 VA. L. REv. 105 (1951).

32. For judicial recognition that false pretense's statutes may, if not carefully construed, be used to circumvent prohibitions of imprisonment for debt, see Daniel v. State, 63 Ga. App. 12, 17, 10 S.E.2d 80, 83 (1940) (to hold defendant guilty "would be in effect to imprison her for a debt") ; State v. Lamoreaux, 13 N.J. Super. 99, 102, 80 A.2d 213, 214 (App. Div. 1951) (conviction vacated because, inter alia, the statute "is not to be used as a means of enforcing civil liability"); Commonwealth v. Hutchinson, 2 Pars. Eq. Cas. *309, $* 310$ (Pa. C.P. 1843) (session of Pennsylvania legislature which abolished imprisonment for debt also enacted false pretenses statute; court holds statute must be construed narrowly to avoid negating abolition of debt imprisonment); cf. State v. Nelson, 58 S.D. 562, 237 N.W. 766 (1931) (bad check statute held unconstitutional as resulting in imprisonment for debt); State v. Morris, 85 Utah 210, 216, 38 P.2d 1097, 1100 (1934).

The imprisonment for debt problem is greatest in jurisdictions where loss is an element of the crime. See notes 33-34 infra and accompanying text; State v. Nelson, supra. However, one court in a jurisdiction where the loss rule was in effect has held that the jury should be allowed to acquit if it finds that the prosecution was brought merely to assist the complaining witness in coercing payment of the debt. State v. Rivers, 58 Iowa 102, 12 N.W. 117 (1882). But see State v. Jackson, 128 Iowa 543, 105 N.W. 51 (1905).

33. Cf. Parnass, supra note 31, at 571; Ford, supra note 31, at 47; Note, 1952 WIS. L. Rev. 764. See also Winer, An Appraisal of Criminal and Civil Penalties in Fcderal Tax Evasion Cases, 33 B.U.L. REv. 387 (1953).

Wholly apart from the loss rule, some courts openly employ false pretenses statutes to coerce payment. Cf. Wilson v. State, 84 Ga. App. 703, 706, 67 S.E.2d 164, 168 (1951) (defendant to serve twelve months in jail and to make restitution of $\$ 800$, with probation conditioned on restitution). Several statutes provide for restitution as part of the sentence. E.g., Mo. Ann. Code Gen. Laws art. 27, \$ 172 (Flack 1951) ; Nev. Comp. Laws $\$ 10391$ (1929); Tenn. Cone Ann. \$ 40-2716 (1955); Wyo. Conp. Stat. Ann. \$ 9-907 (1945). 
innocence of the original conduct, it gears the statute to the private purposes of the creditor rather than the public purposes of the criminal law. ${ }^{34}$

False pretenses statutes perform an essential criminal law function. Every year, frauds and swindles inflict on the public many millions of dollars of damage. ${ }^{35}$ And in many instances, the operators of fraudulent schemes are amenable to prosecution only under false pretenses statutes. ${ }^{36}$ But while these statutes must be justified primarily in terms of their usefulness in deterring and punishing such schemes, they may also serve a legitimate function outside the realm of palpable criminality; indeed, they must do so, for criminal statutes cannot be made to distinguish between "criminals" and "businessmen." In any event, a conviction for false pretenses cannot be secured unless a jury finds that a misrepresentation was made with intent to defraud. ${ }^{38}$ Such intent can be found in the credit context only if the jury believes the debtor intended harm to the creditor to result in the ordinary course of events. ${ }^{39}$ Undoubtedly, commercial lies told with such an intent warrant criminal punishment. Nevertheless, the problem remains that juries have tended to convict in many instances on little more than a showing that a misrepresentation was made. ${ }^{40}$ It was at

34. See, generally, 1 Wharton, Criminal Law $\$ 17$ (12th ed. 1932).

35. In 1935 the National Association of Credit Men identified 800 persons engaged in credit racketeering. In that year the average fraud netted $\$ 12,000$, and the annual tribute was $\$ 20$ million. Ellison \& Brock, The Run for Your Money 207 (1935). In 1945 the cost of fraud was estimated to be $\$ 100$ million per year. Foster, Gyps and Swinders 1 (Public Affairs Pamphlet No. 109, 1945). A commodities speculator recently pleaded guilty to obtaining $\$ 3$ million by false pretenses. N.Y. Times, March 20, 1956, p. 3, col. 7.

36. See note 2 supra.

The most serious loophole in the false pretenses statute is that it does not punish false promises, estimates or opinions unless accompanied by misstatement of fact. See Carr v. State, 60 Ga. App. 590, 4 S.E.2d 500 (1939) ; State v. Zingher, 302 Mo. 650, 259 S.W. 451 (1924); State v. Lamoreaux, 13 N.J. Super. 99, 80 A.2d 213 (App. Div. 1951). Pearce, Theft by False Promises, 101 U. PA. L. Rev. 967, 979 (1953), criticizes the rule, pointing out exceptions in mail fraud statutes. By taking advantage of such gaps professional swindlers avoid prosecution. See Ellison \& Brock, The RUN for Your Money 7 (1935). Nebraslia has closed this loophole. NeB. Rev. Stat. \$28-1207 (1947); see Notes, 33 NeB. L. REv. 491 (1954), 5 U. FLA. L. REv. 63, 71 (1952) (proposed statute punishing false promises).

37. The criminal law is directed at acts rather than at persons; there can be no crime without an act. 1 BURdICK, LAw of CRIMIE $\$ \$ 96-100$ (1946).

The original false pretenses statute was intended to punish and deter misrepresentations that injure or prejudice trade and credit. 30 Gro. 2, c. 24 (1757) preamble. See, generally, Pearce, supra note 36 . Trade and credit may be injured as effectively by "white collar" frauds as by more colorful confidence games and outright swindles. For an account of alleged misrepresentations relating to uranium stock, made by an established broker, which resulted in losses of $\$ 15$ million, see N.Y. Times, April 27, 1956, p. 1, col. 6.

38. 1 Bishop, CRIMinal Law $\$ \$ 204,285-88$ (9th ed. 1923).

39. 2 BURDICK, LAW OF CRIME $\$ 649$ (1946) ("the intent to deprive the owner wholly of his property").

40. See, e.g., cases cited notes $6,22,32$ supra, all of which involved jury verdicts of conviction, some sustained on appeal.

Defense pleas based on subjectively innocent intent are seldom successful. See Agnew 
least in part to limit juries' ability to find intent to defraud, and thus to prevent unwarranted convictions, that courts created the loss rule and its variants, whose inadequacies are highlighted by the Nelson case. ${ }^{41}$

The policy problems involved in application of false pretenses statutes to credit transactions can best be resolved by abolishing the loss rule, and instead construing the statute to forbid misrepresentations which, when made, exposed a creditor to an unreasonable risk of loss. This construction would serve better than the loss rule the courts' purpose of exempting "naked" lies and reserving punishment for lies which the community has a substantial interest in preventing. ${ }^{42}$ Thus the debtor who provided adequate security, and whose overstatement of security therefore created only a minimal amount of danger to the creditor, could not be convicted even if fortuitous subsequent events prevented payment. ${ }^{43}$ At the same time, the suggested interpretation would avoid the anomalous result made possible by the loss rule, that an unsuccessful swindler may avoid prosecution by making restitution. In addition, the proposed interpretation would minimize misuse of the statute to coerce payment of debts. It would eliminate imprisonment for debt in a logical sense, since eventual payment or nonpayment would play no part in determining guilt. It probably would not eliminate payment altogether as a factor in determining whether criminal prosecutions are begun or carried to completion. Creditors who have been duly paid are perhaps unlikely to complain in the first instance, and both prosecutors and judges are apt to respond with clemency to restitution. But by insuring that convictions cannot be secured unless a showing is made that, wholly apart from the defendant's ultimate failure to pay, the defendant's misrepresentation created danger to the community and hence should be punished, the interpretation insures that the interest of the creditor can at most only coincide with the interest of the community in enforcing the criminal law.

An "unreasonable risk" standard could be administered easily and effectively, despite apparent problems of proof and predictability. In the context of secured credit transactions, the reasonableness of the risk created by a debtor's misrep-

v. United States, 165 U.S. 36, 53 (1897) ; People v. Lee, 259 Mich. 355, 243 N.W. 227 (1932). See also Remington \& Helstad, The Mental Elenent in Crime-A Legislative Problem, 1952 WIs. L. REv. 644; Note, 28 TEMr. L.Q. 470 (1955). A showing of all the objective elements of a crime is deemed to constitufe prima facie evidence of intent, on the principle that a person intends the necessary and natural consequences of his acts. See Reynolds v. United States, 98 U.S. 145, 167 (1878); Wardlaw v. United States, 203 F.2d 884 (5th Cir. 1953) ; 1 Burdick, Law of Crime $\$ \$ 118,124$ (1946) : 1 Whakton, Criminal LAw $\$ 147$ (12th ed. 1932).

41. See cases cited notes 6-8 supra.

42. See notes $25-27$ supra and accompanying text.

43. For a case apparently applying a "risk" test in order to reach this result, see State v. Morris, 85 Utah 210, 216, 38 P.2d 1097, 1100 (1934).

44. Cf. Commonwealth v. Carr, $28 \mathrm{~Pa}$. Super. 122 (1905) (false pretenses a misdemeanor which the magistrate in his discretion may dismiss upon defendant's making restitution).

On the effect of reparation generally, see 1 WharTon, CRIMINAL Law $\$ \$ 192,413$ (12th ed. 1932). 
resentation would depend on the sufficiency of the security actually provided. ${ }^{45}$ The security provided should be deemed sufficient if it is equal in value to the money or property obtained by the debtor in the secured transaction, ${ }^{46}$ or to the amount of security customarily made available in similar transactions, whichever is greater. ${ }^{47}$ Evidence of a customary standard could readily be produced in most cases, and directed verdicts together with precise instructions would limit the jury's discretion and thus provide some measure of predictability. Where the misrepresentation occurred in the course of an unusual transaction for which no customary standard could be shown, the measure of sufficiency would be the value of the money or property obtained by the debtor in the secured transaction. This standard of a fixed amount is, no doubt, to some extent commercially unrealistic, since creditors often require security greater in amount than the debt secured. It seems preferable to a test of reasonableness, however, because of its greater certainty and susceptibility of proof. 48

To sustain conviction of the crime of false pretenses in the context of commercial credit transactions, the state should have to prove, and the jury should have to find, that the debtor by misrepresenting his security exposed his creditor to an unreasonable risk of loss in the ordinary course of events. Under prevailing standards for commercial conduct, misrepresentations which threatened no harm when made should not be criminally punishable whether or not

45. See State v. Palmer, 50 Kan. 318, 32 Pac. 29 (1893); State v. Zingher, 302 Mo. 650, 259 S.W. 451 (1924); accord, State v. Casperson, 71 Utah 68, 262 Pac. 294 (1927).

46. Cf. State v. Palmer, supra note 45 (sufficient collateral to save creditor from loss); State v. Zingher, supra note 45 ("ample assets to meet his liabilities at the time he obtained the loan") ; State v. Morris, 85 Utah 210, 38 P.2d 1097 (1934) ("sufficient security to satisfy"). Other courts require the state to prove that the debtor was insolvent. E.g., People v. Holtzman, 272 I1l. 447,112 N.E. 370 (1916). But this standard is valid only where a creditor is depending on the general financial reliability of a debtor rather than on specific property; if the creditor were limited to general credit, bargaining for security would be pointless.

47. Obviously a creditor wants and is entitled to receive a reasonable spread between debt and security. Specific security is, however, only one aspect of a debtor's financial reliability which is considered when credit is extended. For a thorough analysis of how businessmen determine credit limits and examples of the customary spread between a buyer's resources and credit allowed him in mercantile, banking and retail transactions, see IroNs, op. cit. supra note 20 , at 16-27, 431-44.

The UNIFORM COMIMERCIAL CODE $\$ 2-302$, and the common law of some states, prevent enforcement of unconscionable provisions of a contract in a civil action. Note, 63 Y L.J. 560 (1954). A fortiori, such a contract provision should not be the basis of criminal liability. Cf. 2 Bishop, Crininal LAw $\$ 463$ (9th ed. 1923); Coe, Doctrine of Entrapmont, JAG J., Nov. 1951, p. 3.

48. If the property given as security was perishable, subject to sudden fluctuations in rnarket value, or otherwise peculiarly vulnerable to impairment, the court might allow the jury to decide that the creditor was entitled to an amount of security reasonably greater than the value of the property obtained, $c f$. Deese v. State, 127 Fla. 583, 173 So. 439 (1937), or an amount shown to be customary when dealing with security of the type involved. For a discussion of external factors which influence credit policy, see Irons, op. cit. supra note 20 , at $28-41$. 
injury occurs afterward. And debtors should not be differentiated for purposes of criminal punishment by their ability to respond to contractual obligations. Only by emphasizing the situation of the parties at the time of contracting can the courts avoid the dangers which the $N$ elson interpretation creates, that harmless lies will be punished and imprisonment for debt effected.99

49. The recommendations here made could be implemented immediately at the trial court level in most American jurisdictions, since no contrary authority exists, and in the remainder at the appellate court level, since the proposed interpretations are clearly a permissible gloss on the broad terms of the false pretenses statutes. In the few jurisdictions where undesirable interpretations are established, so that judicial change is unlikely, see cases cited notes 7, 25 supra; Green v. State, 144 Tex. Crim. 186, 161 S.W.2d 114 (1942); In re Rudebeck, 95 Wash. 433, 163 Pac. 930 (1917), existing false pretenses statutes should be amended substantially as follows:

Provided, however, that no debtor who obtained something of value from a creditor by false pretense concerning the value of the security available for repayment of the debt or obligation shall be convicted unless the false pretense uttered by him exposed his creditor to an unreasonable risk of loss in the ordinary course of events.

A creditor is exposed to an unreasonable risk of loss where at the time of the transaction the security described was not equal in value: (1) to an amount customarily made available in such transactions, or (2) to the value of the property obtained, whichever is greater. 